\title{
EFFECT OF POLY(AMIC ACID) AND POLYIMIDE ON THE ADHESIVE STRENGTH AND FRACTURE TOUGHNESS OF EPOXY RESIN
}

\author{
M. BAKAR, M. OKULSKA-BOŻEK, AND M. ZYGMUNT
}

Radom University of Technology, Radom, Poland

The present work investigates the effect of polyimide and poly(amic acid) content on the properties of epoxy resin. Charpy impact strength increased by $80 \%$ and $70 \%$ with the addition of $10 \mathrm{wt} . \%$ poly(amic acid) and $15 \mathrm{wt} \%$ polyimide, respectively. However, the flexural strength was improved by $95 \%$ and $73 \%$ (in comparison with neat epoxy resin) by the addition of $5 \mathrm{wt} . \%$ polyimide and $5 \mathrm{wt} . \%$ poly(amic acid), respectively. Moreover, the addition of $10 \mathrm{wt} . \%$ polyimide resulted in two fold increase of impact adhesive strength, while the tensile adhesive strength of epoxy was increased by $70 \%$ with only $5 \mathrm{wt} . \%$ polyimide. Infrared spectra showed that the obtained compositions containing polyimide or poly(amic acid) exhibited a semi-interpenetrating polymer networks structures, characterized by a relatively high flexibility and very good mechanical properties.

Keywords: epoxy resin, polyimide and poly(amic acid), adhesive strength, impact strength.

Cured epoxy resins are characterized by very good chemical resistance, good processing properties and excellent adhesion to metals and glasses. These properties allow them to be used in various applications such as building, electronics, car industry. However, their field of application is seriously limited by their low impact strength and poor resistance to crack propagation. Different types of modifiers were used to improve the mechanical properties of epoxy resins [1]. Ductile thermoplastics have been used among others to overcome the drawback of the loss of thermal properties induced by the incorporation of reactive liquid rubbers such as butadiene - acrylonitrile copolymers terminated with carboxyl or amine groups [2-6].

Agag and Takeichi used the polyimide containing hydroxyl groups to modify a commercial epoxy resin [7]. Their results showed that the tensile modulus of the obtained films increased with increasing polyimide content, but with no significant change in the elongation at break. Moreover, the thermogravimetric analysis showed an increase in the films thermal stability with the increase of the modifier content.

Gaw and his research group analyzed the cure behavior by differential scanning calorimetry (DSC) and thermogravimetric analysis (TGA) of an epoxy resin cured with poly(amic acid)s [8]. The thermal analysis demonstrated a complex reaction between the polymer matrix and the hardener. However, they did not observe any phase separation and attributed the observed phase behavior to a unique in situ reaction.

However, Harris and coworkers synthesized a series of organo-soluble aromatic polyimides from four different dianhydrides and two different diamines and used them as toughening agents for epoxy resins [9]. The authors studied the dependence of the obtained polyimides structure on the solubility, thermal and mechanical properties of the epoxy based compositions as well as they selected the polyimide to be used as an effective toughening agent for epoxy resins.

Jin and Park prepared and used a hyperbranched polyimide (HBPI) to modify diglycidyl ether of bisphenol A (DGEBA) [10]. The thermogravimetric analysis results showed that the thermal stability of the DGEBA/HBPI blends did not obviously change

Corresponding author: M. BAKAR, e-mail: mbakar@wp.pl 
as the amine-terminated hyperbranched polyimide content increased. However, they noted an increase of the glass transition temperature as well as an enhancement of the critical stress intensity factor $\left(K_{C}\right)$ and impact strength (IS). The addition of 4 wt.\% polyimide resulted in 2.5 and 2 times increase of $K_{C}$ and IS values. Furthermore, SEM analysis revealed the occurrence of shear deformation, which led to the crack propagation deceleration within the sample.

More recently, Huang and al. prepared nanocomposites based on polyimide and epoxy resin [11]. The dynamic mechanical analysis showed a significant increase of the crosslink densities of the obtained polyimide-epoxy nanocomposites. However, compressive modulus, hardness and coefficient of thermal expansion changed only slightly.

The purpose of the present work was to investigate the effect of polyimide and poly(amic acid) content on the adhesive properties and fracture toughness of epoxy resin.

Experimental. Materials. The following ingredients were used in the present work:

- Epoxy resin: Epidian 5 from Organika Sarzyna, Nowa Sarzyna - Poland, having an average molecular weight of 380 and epoxy number of $0.490 \ldots 0.520 \mathrm{~mol} / 100 \mathrm{~g}$;

- Polyimide: trade name P-94 from Lenzing AG;

- Hardener: triethylene tetramine (trade name Z1) obtained from Organika Sarzyna;

- Oxydianiline from Fluka AG;

- Pyromellitic dianhydride (Aldrich).

Synthesis of poly(amic acid). Poly(amic acid) was prepared from oxydianiline $(0.005 \mathrm{~mol})$ and pyromellitic dianhydride $(0.005 \mathrm{~mol})$ in a solution of tetrahydrofurane and methanol (4:1 by wt.) by means of polyaddition and dianhydride ring opening method. Oxydianiline and pyromellitic anhydride were purified by sublimation method under nitrogen atmosphere After the complete dissolution of diamine under constant mixing, solid dianhydride was added. The reaction was carried out at room temperature for $2 \mathrm{~h}$.

Samples preparations. Epoxy formulations containing polyimide. Polyimide was first dissolved in a specific amount of dimethylformamide (ratio: $5 \mathrm{~g} / 45 \mathrm{~g}$ ) to yield a $10 \%$ solution. The dissolution of the polymer was carried out under continuous mixing by means of mechanical stirrer for $10-12 \mathrm{~h}$ and a temperature of $100^{\circ} \mathrm{C}$. All the solvents were purified before use. Different amounts of polyimide were added to epoxy resin and mixed for 5 min using a mechanical stirrer until obtaining a homogeneous mixture. Then a specific amount of hardener Z1 (12 g Z1/100 g resin) was added followed by mixing for an additional $5 \mathrm{~min}$. The formulations were then poured to metallic forms coated with anti-adhesive agent and having the required geometries for impact and flexural strength measurements.

A specific amount of formulations was spread on solvent cleaned metallic surfaces for adhesive strength under impact and tensile conditions.

All samples were then submitted to curing at room temperature for $24 \mathrm{~h}$ followed by post curing at $120^{\circ} \mathrm{C}$ for $3 \mathrm{~h}$.

Epoxy samples containing poly (amic acid). Epoxy resin and poly(amic acid) were mechanically mixed until a homogeneous mixture was obtained. Then the hardener was incorporated and mixing was continued for an additional $5 \mathrm{~min}$. The formulations were then poured to metallic forms as previously. Moreover, similarly to polyimide based compositions, a constant amount of adhesive was spread on solvent cleaned metallic surfaces prior to adhesive strength measurements.

Curing and post-curing processes were carried out as for polyimide samples.

Properties evaluation. The impact strength was evaluated on samples having $8 \mathrm{~cm}$ in length, $1 \mathrm{~cm}$ in width, $4 \mathrm{~mm}$ in thickness and $1 \mathrm{~mm}$ of notch using Zwick 5102 apparatus according to Charpy method and Polish norm PN-81/C-89029. 
The flexural strength was evaluated on samples having the following geometries: $16 \mathrm{~mm} \times 10 \mathrm{~mm} \times 4 \mathrm{~mm}$ using a Dynstat apparatus according to Polish norm PN-72/ C-04243.

The adhesive strength under impact conditions was measured using a Zwick 5102 apparatus by estimating the work needed to separate two jointed metallic plates of $1 \mathrm{~cm}^{2}$ surface area which were adapted to the Charpy hammer.

The tensile adhesive strength was evaluated according to Polish norm PN-69/ C-89301 using two metallic cylinders having $1 \mathrm{~cm}^{2}$ in the base surface area and Instron tensile tester 5566 with a deformation rate of $5 \mathrm{~mm} / \mathrm{min}$.

Infrared spectrophotometer FT-IR Perkin Elmer 1000 PC was used for the analysis of obtained compositions structure.

Results and discussion. The Charpy impact strength (IS) is shown in Fig. $1 a$ as a function of polyimide (PI) and poly(amic acid) (PAA) content. It can be noted, that IS increases with increasing amount of PI and PAA. Maximum improvement of $70 \%$ (in comparison with nonmodified resin) is reached with $15 \mathrm{wt} . \%$ PI. The impact strength enhancement might be explained by the significant polyimide toughness at room temperature. Moreover, the addition of $10 \mathrm{wt} . \%$ PAA leads to approximately $80 \%$ optimum enhancement of IS in comparison with that of neat epoxy resin. The impact strength enhancement by poly(amic acid) incorporation can be attributed to the formation of ether groups arising from PAA which increases the flexibility of the obtained composition. However, the IS decrease (induced by the higher amount of PAA) might be explained by the presence of an appreciable amount of stiff segments which prevent the reactions of ether groups responsible for flexibility improvement.

From Fig. $1 b$, it can be noted that as polyimide (PI) and poly(amic acid) (PAA) content is increased, the flexural strength as measured under two point bending method increases and then decreases. The maximum flexural strength, representing approximately $95 \%$ and $73 \%$ in comparison with neat epoxy resin, is obtained with $5 \mathrm{wt} . \%$ of PI and PAA, respectively.
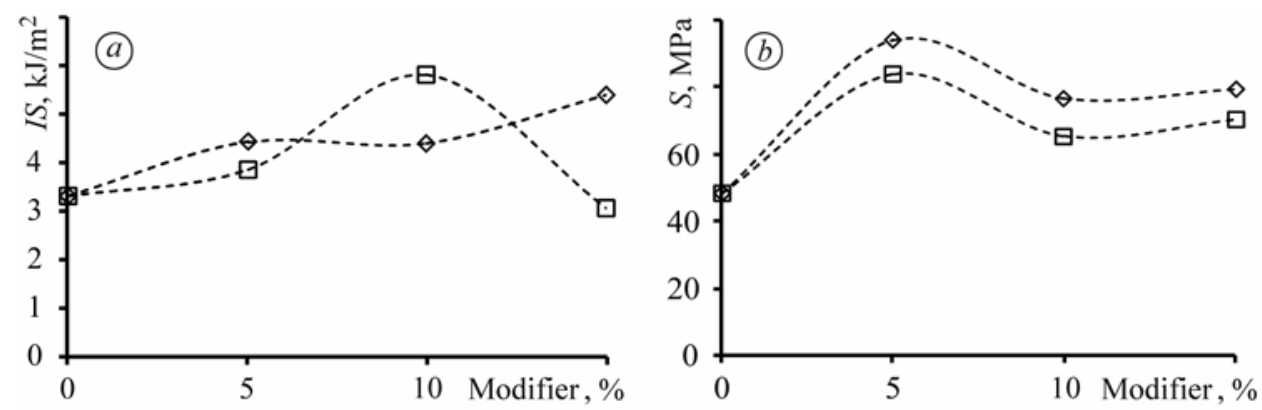

Fig. 1. Effect of polyimide $(\diamond)$ and poly(amic acid) $(\square)$ content on impact strength (IS) of the epoxy resin $(a)$ and on its flexural strength $(\mathrm{S})(b)$.

As shown in Fig. 2, the flexural angle at break measured under two-point bending mode, increases with the addition of polyimide but is not significantly affected by poly(amic acid) incorporation. As with impact strength results, the maximum value of flexural angle is exhibited by the composition containing $10 \mathrm{wt} \%$ of polyimide. The resin flexibility improvement attains $50 \%$ in comparison with that of nonmodified epoxy resin. The epoxy composition flexibility enhancement might be attributed to the increase of the free volume that is provided to the systems leading to more chain or segment movements. Consequently, the modified samples undergo larger deformations before the occurrence of fracture. Moreover the increase in composition flexibility may explain the increase of the crack propagation resistance (Fig. 1a). 


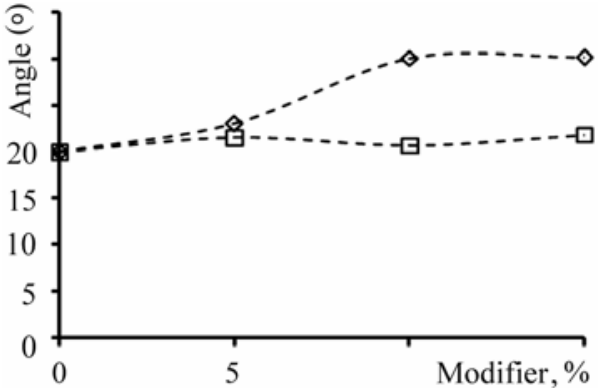

Fig. 2. Effect of polyimide $(\diamond)$ and poly(amic acid) $(\square)$ content on the flexural angle at break.
The effect of polyimide and poly(amic acid) content on the impact adhesive strength as well as tensile adhesive strength are illustrated in Table 1. By impact adhesive strength (IAS), we mean the energy needed to separate under impact conditions two metallic plates jointed by the epoxy based composition, while the tensile adhesive strength (TAS) is measured under tensile conditions. It can be noted that, as the modifier content increases, IAS increases and then decreases. The composition containing $10 \mathrm{wt} . \%$ polyimide $(\mathrm{PI})$ shows maximum IAS value which

corresponds to almost twice the IAS value of unmodified epoxy resin. We can explain the IAS enhancement by the presence of $(-\mathrm{NH}-)$ polar groups in the formed epoxy/polyimide structure. However, for poly(amic acid) based compositions, maximum improvement equating $65 \%$ in relation with neat epoxy resin, is reached with $5 \mathrm{wt} . \% \mathrm{PAA}$. It is worth noting that all PI and PAA based compositions exhibits higher or at least equal impact adhesive strength values as the pristine epoxy samples cured with triethylene tetramine. We can further observe that as the amount of PI increases, the tensile adhesive strength increases then decreases attaining maximum value, representing $70 \%$ increase in comparison with unmodified epoxy resin, with only 5 wt.\% PI. The composition containing $15 \mathrm{wt} . \%$ polyimide exhibit higher TAS values than the neat resin.

Table 1. Values of tensile and impact adhesive strength as a function of polyimide and poly(amic acid) content

\begin{tabular}{|c|c|c|c|c|}
\hline \multirow{2}{*}{$\begin{array}{c}\text { Modifier } \\
\text { content, wt.\% }\end{array}$} & \multicolumn{2}{|c|}{ Impact adhesive strength, MPa } & \multicolumn{2}{c|}{ Tensile adhesive strength, MPa } \\
\cline { 2 - 5 } & Polyimide & Poly(amic acid) & Polyimide & Poly(amic acid) \\
\hline 0 & 1.4 & 1.4 & 5.6 & 5.6 \\
\hline 5 & 1.5 & 2.3 & 9.4 & 3.2 \\
\hline 10 & 2.8 & 1.9 & 8.6 & 3.4 \\
\hline 15 & 1.6 & 1.7 & 5.8 & 7.8 \\
\hline
\end{tabular}

Moreover, it can be noted that the addition of 5 and $10 \mathrm{wt} \%$ of poly(amic acid) does not result in TAS improvement. However, the enhancement is relatively quite significant ( $40 \%$ increase in comparison with nonmodified epoxy resin) with the addition of $15 \mathrm{wt} . \%$ PAA. The tensile adhesive strength enhancement is most probably due to the significant viscosity increase induced by poly(amic acid) imidization.

To analyze the reaction between the epoxy resin and poly(amic acid), compositions containing the epoxy resin without curing agent and epoxy resin modified with poly(amic acid) and polyimide were prepared and tested for their infrared spectra.

In Fig. $3 a$ infrared spectra of virgin non-crosslinked epoxy resin and composition containing $35 \mathrm{wt} \%$ of poly(amic acid) are presented.

The analysis of infrared spectra (IR) spectra of epoxy resin containing $35 \mathrm{wt} . \%$ PAA (Fig. 3b) indicates that the peak appearing at $915 \mathrm{~cm}^{-1}$ and corresponding to epoxy groups is smaller than in epoxy resin without curing agent, as shown in Fig. $3 a$. The decrease of the height of the mentioned peak confirms the occurrence of chemical reaction(s) between epoxy resin and poly(amic acid). 

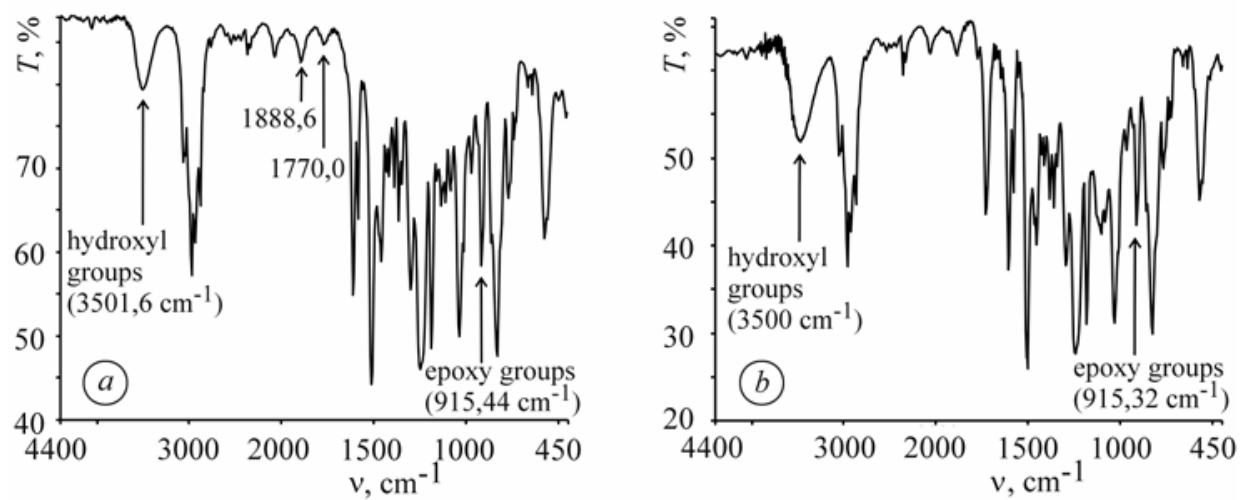

Fig. 3. Infrared spectra of epoxy resin without curing agent $(a)$ and containing $35 \mathrm{wt}$ \% poly(amic acid) (b).

The poly(amic acid) imidization results in the formation of imide groups confirmed by the presence of peaks appearing at 1787 and $1728 \mathrm{~cm}^{-1}$, which are characteristic for the vibrations of $\mathrm{C}=\mathrm{O}$ of imide groups. These bands are shifted towards the lower values (1770 and $1720 \mathrm{~cm}^{-1}$ according to literature), which is the result of grafting between the networks as well as physical interaction between the two involved polymers. This confirms the formation of a semi-interpenetrating polymer network type structure with physical and chemical bonding between polymer matrix and polymeric modifier.

Infrared spectra of epoxy resin cured with trietylenetetraamine for $3 \mathrm{~h}$ at a temperature of $110^{\circ} \mathrm{C}$ is illustrated in Fig. $4 a$. However, peaks confirming the existence of hydroxyl as well secondary amine groups is shifted to $3422.5 \mathrm{~cm}^{-1}$. This peak is higher in the case where epoxy resin is cured at the lower temperature, indicating that crosslinking takes place in the bulk of the specimen.
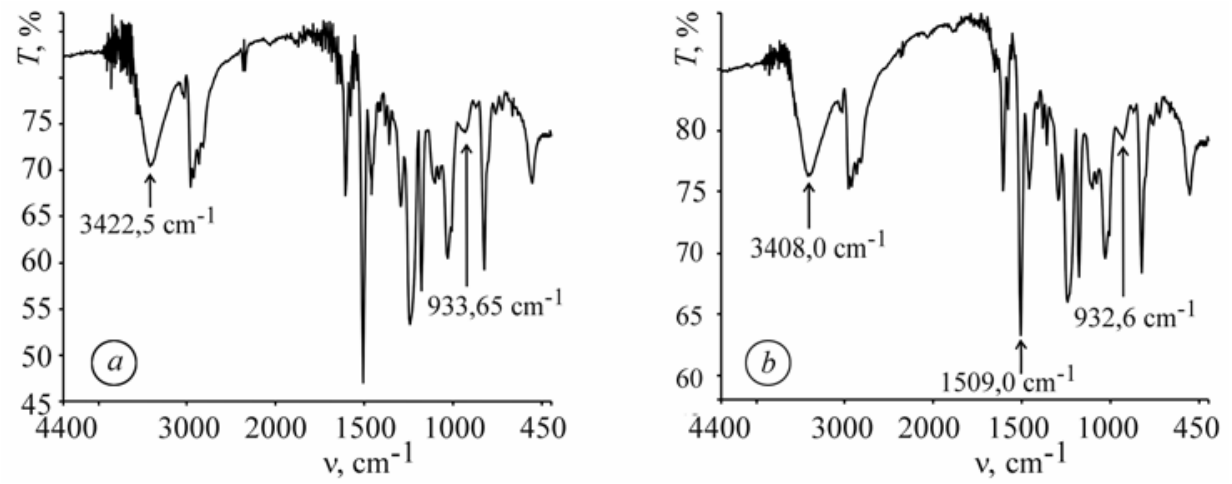

Fig. 4. Infrared spectra of epoxy resin cured with trietylenetetraamine $\left(T=110^{\circ} \mathrm{C}, 3 \mathrm{~h}\right)(\mathrm{a})$ and modified with $10 \mathrm{wt} . \%$ of polyimide $(b)$.

However, one can observe in both cases the appearance of a small peak corresponding to epoxy groups, which confirms the complete curing of the epoxy resin.

From infrared spectra of epoxy resin composition containing $10 \mathrm{wt} . \%$ of polyimide (PI) presented in Fig. $4 b$, one can observe, that the peak at $1509.0 \mathrm{~cm}^{-1}$ is smaller than that of uncured epoxy resin (Fig. 3a), confirming thus, that the addition of polyimide leads to the physical as well as chemical modification of epoxy resin.

The peak appearing at $3408.0 \mathrm{~cm}^{-1}$, which corresponds to the vibrations of $-\mathrm{OH}$ groups is more intensive and insignificantly shifted to higher intensities, which demonstrates the presence of higher amount of such groups in the considered system. 
The reaction between epoxy resin Epidian 5 and poly(amic acid) can take place through the reaction of epoxy groups with amine groups of poly(amic acid) as follows (scheme 1):
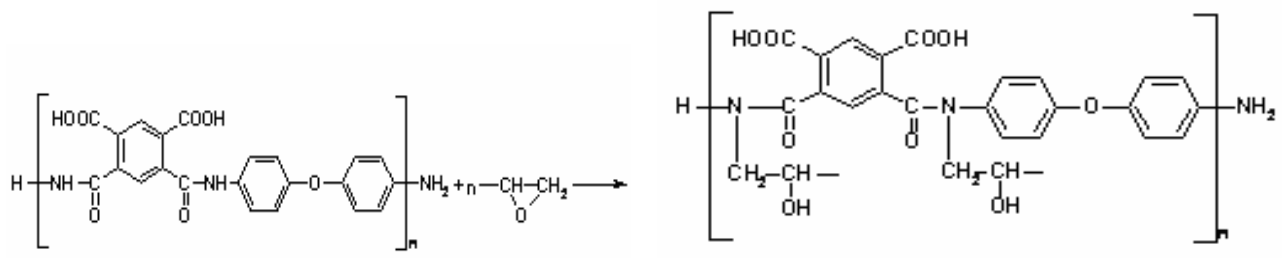

\section{Scheme 1}

The epoxy groups will react further to yield a more branched structure as indicated below (scheme 2 ):
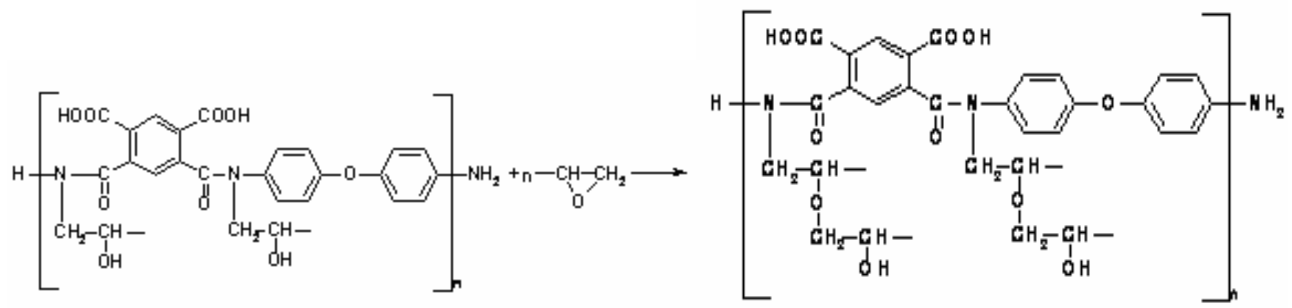

Scheme 2

Moreover, the reticulation reaction of epoxy resin might take place through the reaction of terminal amine groups of poly(amic acid) with epoxy groups of the matrix as follows (scheme 3):<smiles>CCc1ccc(Oc2ccc(N(CCCO)C(=O)c3cc(C(=O)O)c(C(=O)O)cc3C(=O)NCCCO)cc2)cc1</smiles>

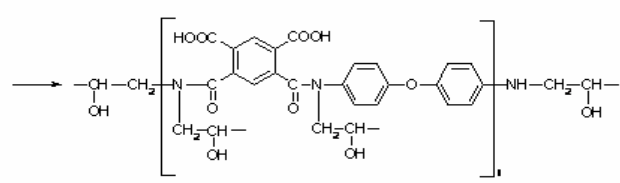

Scheme 3

In this case, the obtained structure is more linear and less branched than in scheme 2, which might explain the flexibility increase of the obtained modified compositions.

\section{CONCLUSIONS}

Based on the obtained results one can make the following conclusions.

The addition of polyimide resulted in the increase of the flexural strength, the deflection angle at break, the impact strength as well as adhesive strength under impact and tensile conditions. The impact strength was improved by approximately $70 \%$ and in comparison with unmodified epoxy resin with the addition of $15 \mathrm{wt} . \%$ polyimide. Moreover, the maximum flexural strength value representing $95 \%$ in comparison with neat epoxy resin, was obtained with 5 wt.\% polyimide. The flexibility of epoxy resin was also improved. The maximum value of flexural angle at break was exhibited by the composition containing $10 \mathrm{wt} . \%$ of polyimide. The enhancement of the mechanical properties of epoxy resin with polyimide might be due mainly to the high elasticity and fracture toughness of the modifier.

The addition of poly(amic acid) resulted in the improvement of impact strength, impact adhesive strength as well as the flexural strength. This latter increased maximally by about $73 \%$ with 5 wt. $\%$ of poly(amic acid), while the impact strength was 
enhanced by approximately $80 \%$ with the addition of $10 \mathrm{wt} . \%$ poly(amic acid), in comparison with that of the neat epoxy resin. The flexibility of epoxy resin was not affected by poly(amic acid) addition.

Infrared spectroscopy analysis revealed that the obtained structures had semi-interpenetrating polymer networks type structures with the occurrence of chemical reaction between poly(amic acid) and epoxy resin.

РЕЗЮМЕ. Досліджено вплив вмісту полііміду (РІ) та поліамідної кислоти (РАА) на властивості епоксидної смоли. Виявлено, що після додавання 10\% PAА та 70\% РI ударна в'язкість збільшується, відповідно, на 80 та 70\% порівняно з немодифікованою смолою. 3 додаванням у полімер 5\% PI та РАА міцність на згин підвищується, відповідно, на 95 та $73 \%$. Крім того, за вмісту 10\% РІ вдвічі збільшилась адгезійна міцність за удару, а за вмісту 5\% РІ адгезія за розриву зросла тільки на 70\% порівняно з немодифікованою смолою. Інфрачервона спектроскопія показала, що композиції епоксидної смоли з РІ та PАA мали напіввзаємопроникні сітчасті структури з відносно високими еластичністю та механічними характеристиками.

РЕЗЮМЕ. Исследовано влияние содержания полиимида (РІ) и полиамидной кислоты (РАА) на свойства эпоксидной смолы. Выявлено, что после добавления 10\% РАА и $70 \%$ PI ударная вязкость увеличивается, соответственно, на 80 и 70\% в сравнении немодифицированной смолой. С добавлением в полимер 5\% PI и РАА прочность на изгиб увеличивается, соответственно, на 95 и 73\%. Кроме того, при содержании $10 \%$ PI вдвое увеличилась адгезионная прочность при ударе, а при содержании 5\% РI адгезия при разрыве возросла только на 70\% в сравнении с немодифицированной смолой. Инфракрасная спектроскопия показала, что композиции эпоксидной смолы с PI та PAА имели полувзаимопроникаемые сетчатые структури с относительно высокими эластичностью и механическими характеристиками.

Acknowledgements. The authors of the paper would like to acknowledge Mr Marcin Kostrzewa for the preparation of FTIR spectra.

1. Kinloch A. J. and Young R. J. Fracture Behaviour of Polymers // Appl. Sci. Publishers. - New York, 1983.

2. Chemical modification of matrix resin networks with engineering thermoplastics / J. L. Hedrick, I. Yilgor, G. L. Wilkes and J. E. McGrath // Polym. Bull. - 1985. - 13, № 3. - P. 201-208.

3. Bucknal C. B. and Partridge I. K. Phase separation in epoxy resins containing Polyethersulphone // Polymer. - 1983. - 24, № 5. - P. 639-644.

4. Hourston D. J., Lane J. M., and MacBeath N. A. Toughening of epoxy resins with thermoplastics II. Tetrafunctional epoxy-polyetherimide blends // Polym. Intern. - 1991. - 26, № 1. - P. 17-21.

5. Rong M. and Zeng $H$. Polycarbonate-epoxy semi-interpenetrating polymer network 2 . Phase separation and morphology // Polymer. - 1997. - 38, № 2. - P. 269-277.

6. Effects of mixing temperatures on the morphology and toughness of epoxy/polyamide blends / S. Kim, J. Kim, S. H. Lim, W. H. Jo, and C. R. Choe // J. Appl. Polym. Sci. - 1999. - 72, № 8. - P. 1055-1063.

7. Agag T. and Takeichi T. Synthesis and characterization of epoxy film cured with reactive polyimide // Polymer. - 1999. - 40, № 23. - P. 6557-6563.

8. Preparation of polyimide epoxy composites / K. Gaw, M. Kikei, M.-A. Kakimoto, and Y. Imai // Reactive \& functional polymers. - 1996. - 30, № 1. - P. 85-91.

9. A study of polyimide thermoplastics used as tougheners in epoxy resins - structure, property and solubility relationships / S. Li, B.-L. Hsu, F. Li et al. // Thermochimica Acta. - 1999. - 340-341. - P. 221-229.

10. Jin F.-L. and Park S.-J. Thermal properties and toughness performance of hyperbranchedpolyimide-modified epoxy resins // J. Polym. Sci. Part B. Polym.-Phys. - 2006. - 44, № 23. - P. 3348-3356.

11. Thermomechanical properties of polyimide-epoxy nanocomposites from cubic silsesquioxane epoxides / J. Huang, Y. Xiao, K. Y. Mya et al. // J. Mater. Chem. - 2004. - 14, № 19. - P. $2858-2863$. 